\title{
The Parsons Steam Turbine
}

\section{Story of the Early Struggles and Final Triumph of a Great Invention}

\author{
By Hector C. Bywater
}

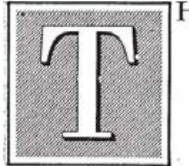

ERE are few themes more inspiring than the history of an epoch-making invention, and its patient development from the germ idea through the various stages which finally culminate in its recognition as a valuable factor in the scheme of human activity; for every such achievement represents a triumph of intellectual force in combination with the dogred perseverance that refuses to be balked of its aim, no matter how formidable the difficulties that have to be overcome. The story of the Parsons steam turbine is full of interest alike from the "human" and the technical points of view, since it tells how. a mechanical device which has revolutionized ship propulsion was brought to its present degree of perfection in spite of obstacles that would have daunted a personality of ordinary caliber. The steam turbine itself is no longer a novelty; its performances are familiar to every student of science and engineering; but of the man whose name is so intimately associated with its development the public has heard very little, because, like most oreat inventors, he does not court publicity. Knowing this, it was with some diffidence that I approached Sir Charles Parsons with a request that he would favor the Scientific American with some personal details of his life and work, and especially of those early days when he was experiencing the vicissitudes that invariably beset the career of the inventor. To this request he most courteously acceded, and I had the pleasure recently of a long conversation with him, in the course of which he talked freely about his work, though much less freely about himself.

The Honorable Sir Charles Algernon Parsons, K.C.B. II.A., LL.D.; D.Sc., F.R.S., was born on June 30,1854 , a younger son of the third Earl of Rosse. His father was not only a nobleman, but a scientist of high repute, who was president of the Royal Societya learned body whose work in the cause of science is too well known to need advertisement-and had built at his Irish home the largest telescope then in existence. It has been well said by one of Sir Charles Parsons' admirers that he is a living example of hereditary genius, encouraged and developed by, wisely-planned vocational teaching. Of his early days he has this to say:

"I was educated on what is called among engineers the 'sandwich system.' My father, rightly or wrongly, had a rooted objection to public school education (as the term is understood in England) and consequently, with my brothers, I was taught by tutors at our home in Ireland. Concurrently I had the advantage of working in well-equipped workshops where my father had constructed his telescopes, and from him learned the first principles of mechanical construction and engineering, for he was a skilled engineer as well as a scientist and an astronomer. After that were as a scientist and an astronomer. After that were
interposed five years of pure and applied mathematics, including the Cambridge Tripos. I recall that the strain was more severe than anything I have experi-

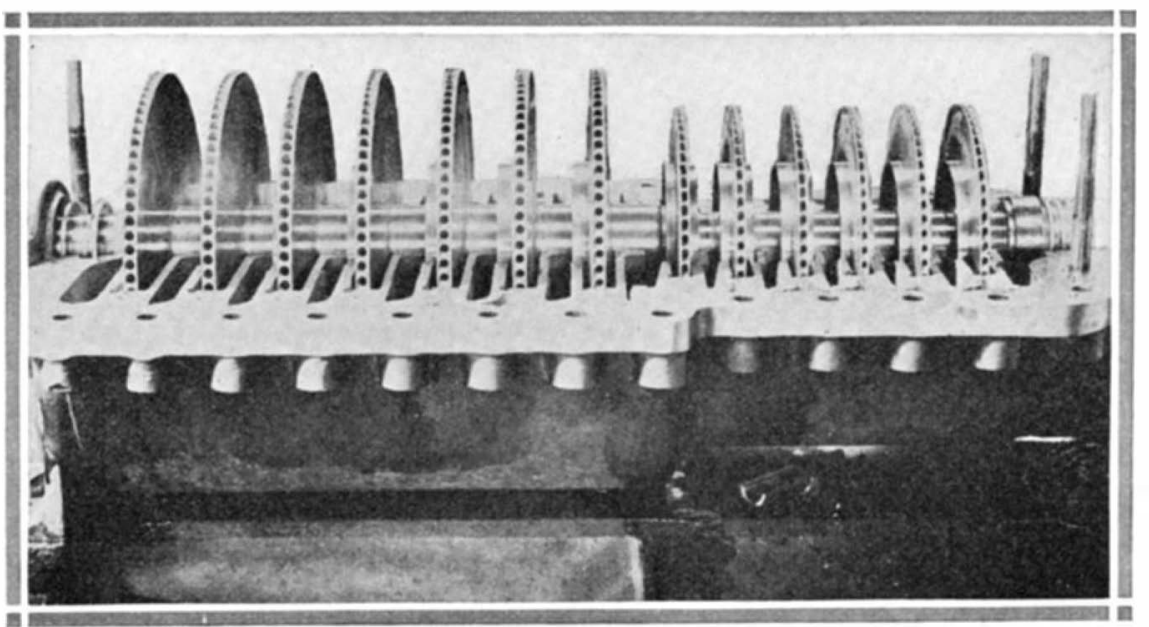

The Inward, Radial-Flow Turbine of 1890, experimental type, later discarded for the parallel-flow interfered with reading."

enced in business life, and, luckily for me, boat racing

While a student of St. John's College, Cambridge, he made several models of an epicycloidal or rotary engine with revolving cylinders, which at a later date was manufactured by him in considerable numbers. The ingenuity shown in designing this intricate machine was an earnest of those intellectual powers that were subsequently to be devoted to a greater problem. Graduating from Cambridge in 1876 with high honors in the Mathematical Tripos, he passed as a premium apprentice to the famous Armstrong workshops at Elswick, where he served for three years in overalls, and cheerfully tackled every job that came to his hand. In this hard school he gained a practical grounding in engineering that stood him in good stead in his later work. "Here," he says, "I learned from Sir William (afterward Lord) Armstrong the methods of mechanical research and construction that have made the Elswick works famous throughout the world, methods closely analogous to those which the workers in physical science have followed from the time of Faraday, methods resulting in the enormous developments in science that have taken place in modern times. In those days I was immensely impressed by Sir William Armstrong's mechanical genius, the layout of his experiments, and his judicious selection of the fittest; and, perhaps above all, by his extraordinary attention to minute details in critical cases of difficulty, while ordinary general administration he deputed to others. When he was busy with a difficult problem he concentrated his attention on it alone, and his powers of mechanical diagnosis were truly remarkable. I picture

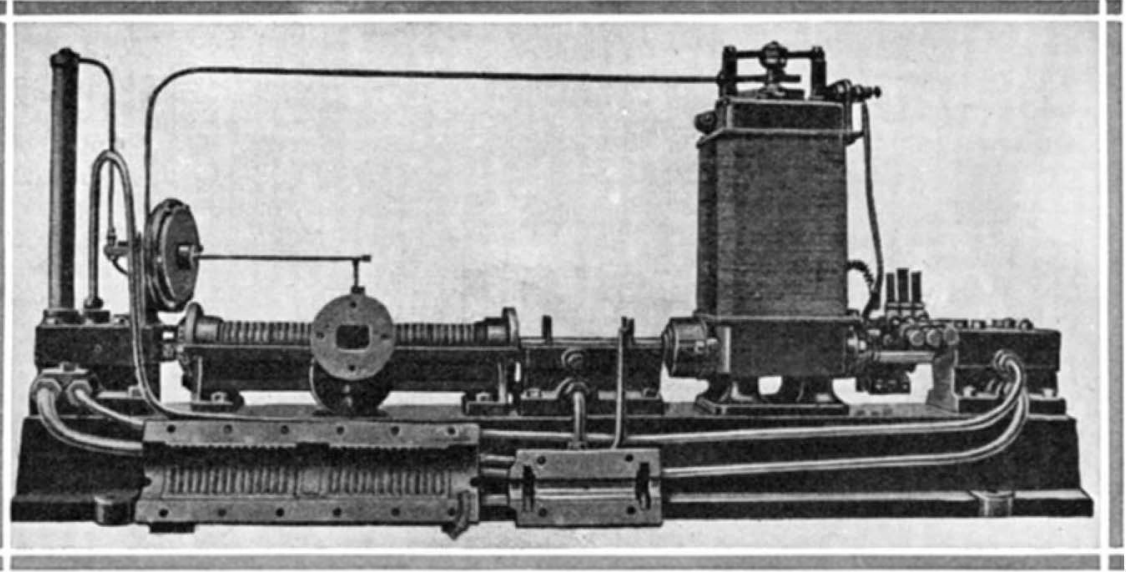

The first experimental Parsons turbine and generator of 1883. It developed go success

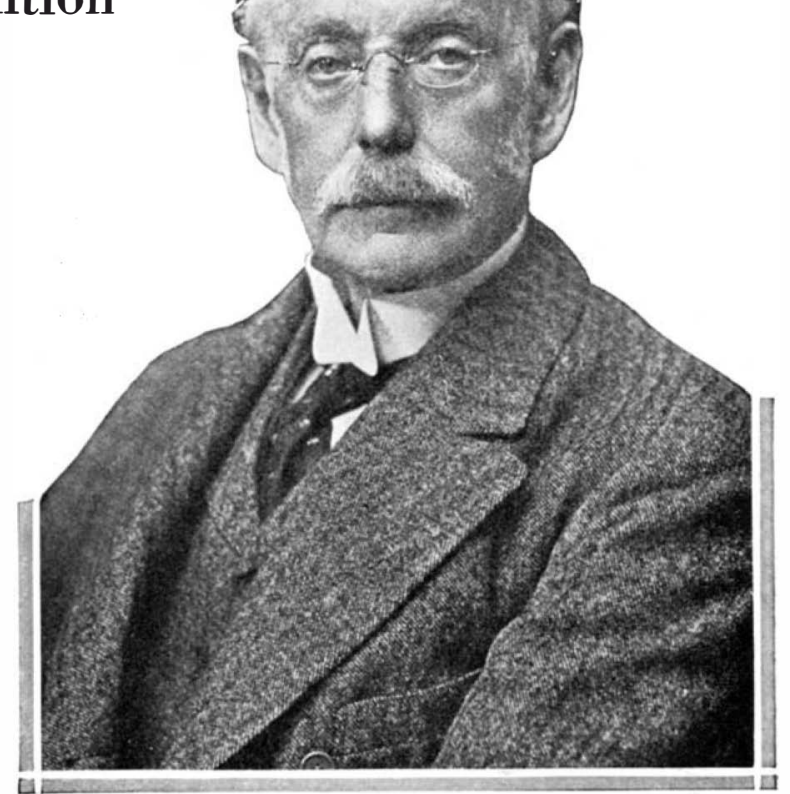

Sir Charles Algernon Parsons, inventor of the steam turbine, is the son of the Earl of Rosse, builder of the famous Rosse Telescope

or working cotton gins.

Parsons, who knew all about these early machines, recognized their deficiencies and determined to approach the problem from an entirely new angle. His knowledge of hydraulics convinced him that without moderate surface velocities and speeds of rotation a thoroughly effective turbine motor could not be developed, and therefore, he says, "I decided to split up the fall in pressure of steam into small fractional expansions over a large number of turbines in series, so that the velocity of the steam nowhere should be great This principle of compounding turbines in series is now always used in all save very small installations, where steam economy is not a prime consideration. It appeared to me, also, that by arranging small drops in pressure at each turbine $\mathrm{I}$ should be more sure of gaining a high efficiency, because then the steam would flow, practically in a non-expansive manner through each individual turbine, in a way ana ogous to that of water in hydraulic turbines, which were known at that date to be highly efficient."

Toward the end of 1883 Parsons became a junior partner in a Gateshead firm, and at once proceeded to put his ideas int practical shape. This he contrived to do so promptly that his first steam turbine

him as the cleverest mechanical engineer I have ever known. In later years, in my own business, I have endeavored to follow the same methods and principles, and have had many more failures than successes, numerically speaking, in the effort to progress as my teachers had done before me; yet the failures should have been soon discerned, and effort concentrated on the successes." over, he took an appointment with Kitsons, of Leeds, fo whom he built many of the epicycloidal engines referred to above. Before this period, however, his thoughts had already turned to the possibility of designing a steam turbine that for certain classes of work would rival if not surpass the reciprocating engine in efficient and economical running. The idea was, of course, not new. The first turbine of which we have any record was Hero's reaction steam wheel, made at Alexandria 2000 years ago. This ancient device was revived in 1837 by one Avery, of Syracuse, New York, who employe it to drive a circular saw, an was built in the following year. Of the parallel-flow ype, it developed 6 horsepower, and was employed for driving a dynamo; in which capacity it proved more than successful enough to justify the inventor in continuing his line of research. After being used for some years this engine was presented to the Science Museum, London, where it now reposes in company with other remarkable inventions of the mechanical era. Encouraged by this initial success, Parsons next designed and built a conpound steam turbine of 10 horsepower, runring at 18,000 revolutions per minute. This, too, was intended for electrical generation, the inventor having meanwhile designed and patented a dynamo that would run at the high speed corresponding to that of the turbine rotor. Turbo-electric plants of this type soon came into great favor, and to that extent the success of the system was already assured. But Parsons was anxious to apply it experimentally to ship propulsion, an idea which he had already elaborated in a paten specification filed in 1884. The realization of the plan had to be postponed, however, for several reasons, one of them being a dissolution of partnership that occurred in 1889, whereby the inventor was deprived of the proprietary rights in his own patents and thus comwelled to forego the further construction of turbine on the parallel-flow system, which was known to be the best and most efficient. So far from discouraging him, however, this check only served to direct his inventive genius into other channels. Establishing his own works at Heaton in 1890 , he built experimenta turbines on the radial-flow principle, succeeding after 


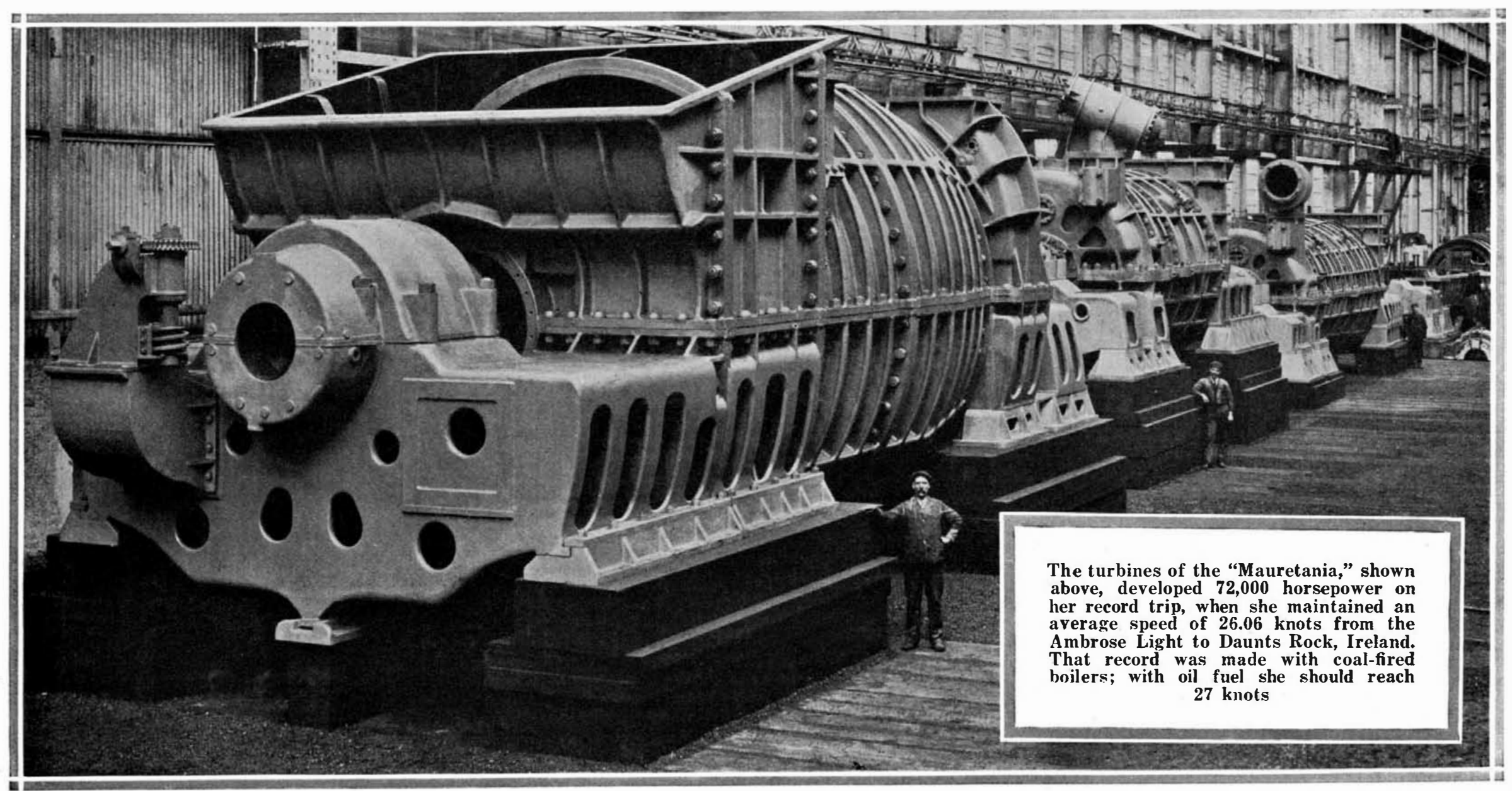

some difficulty in producing and marketing a satisfactory turbo-electric plant on this system. Throughout those five years in which he was debarred from ex-
ploiting his original patents he was continually experimenting with new ideas, all bearing on the efficiency of various elements in the steam turbine, particularly the blading; and when, in 1894 , he recovered his patent rights, the fruits of his indefatigable research work rights, the fruits of his indefatigable research work
soon became manifest. The manufacture of parallelflow turbines was at once undertaken at the Heaton factory, one of the first contracts executed being for a 350-kilowatt turbo-generator set, which in those days was considered a plant of enormous power.

"Irom the first," said Sir Charles, "I realized the possibilities of turbine propulsion for ships, and had deroted much study to the problem, but I was not blind to the special difficulties which stood in the way, notably that of finding a propeller that would work efficiently at the high rate of revolution necessitated by turbine drive. In 1894 I began experimenting with small ship models in a pond at my home at Ryton-on-Tyne, to determine, first, the ship lines best adapted to very high speeds, and next to study propeller action. One of these models, two feet in length, was fitted with clockwork and a twisted rubber cord actuating a twobladed propeller, which turned at 18,000 revolutions per minute and drove the boat at a speed of six knots. Other models followed, and eventually we were able to calculate the propeller efficiency required for a full-size turbine steamboat. At this stage a syndicate was formed for the building of the vessel which afterward became widely noted as the 'Turbinia.' The hull was 100 feet long, 9 feet broad, and drew 3 feet of water on a displacement of 44 tons. She had one doubleended straight-tube boiler, supplying steam to a turbine of the radial-flow pattern, which was coupled to a single propeller shaft. The trials began in 1894, and various sizes and types of propeller were tried, both singly and in multiple, until we found that three screws set on the same shaft gave the best performance. The highest speed attained, however, was only $193 / 4$ knots, with which I was by no means satisfied. Eventually the disappointing result was traced to cavitation, a phenomenon that we were able to study very closely with the aid of a special apparatus and instantaneous photography. The outcome of these experiments was a decision to reequip the 'Turbinia' with three sets of turbines-built this time on the parallel-flow systemand to set three propellers on each shaft, or nine in all. The new engines weighed only 3 tons $13 \mathrm{cwts}$., the total weight of the plant, with boiler, shafting, propellers, etc., amounting to some 22 tons, while the horsepower developed was about 2000 units. This time the results were far more promising. Many trial runs were made at all ranges of speed, the maximum reached being nearly 33 knots. Not only this, but the installation proved both economical in steam consumption and laandy to manipulate, it being possille to work up to top speed in much less time than would have been necessary with reciprocating engines. Another gratifying feature of the tests was the absence of vibration." Mr. Parsons-whose knighthood dates from 1911now decided that the time had come to confound the skeptics who still disbelieved in the new system, an the great naval review held at Spithead in 1897 to celebrate the Diamond Jubilee of Queen Victoria afforded a particularly favorable opportunity for demonstrating the "Turbinia's" powers. Accordingly, the little vessel was quietly steamed down to Cowes roadstead to await the psychological moment. It came when the great fleet of British and foreign warships lay at anchor in several long lines, with royalties and othe distinguished personages from the four quarters of the globe looking on. Suddenly, at the head of one line, there flashed into view a diminutive vessel traveling at incredible speed. Down the long lane of motionless leviathans she shot like an arrow, only a wisp of smoke at her squat funnel, her forefoot well clear of the water and her wake a tumbling rampart of foam that testified to the marvelous speed at which she was moving. Doubling like a hare round the head of the column, she sped between the next line of ships at the same amazing velocity-it was actually 34 knots-and was gone before the onlookers had time to grasp the significance of what they had seen.

"I have a vivid recollection of that day," said Sir Charles, "having myself acted as chief engineer during the run. Some hours after we had returned to our

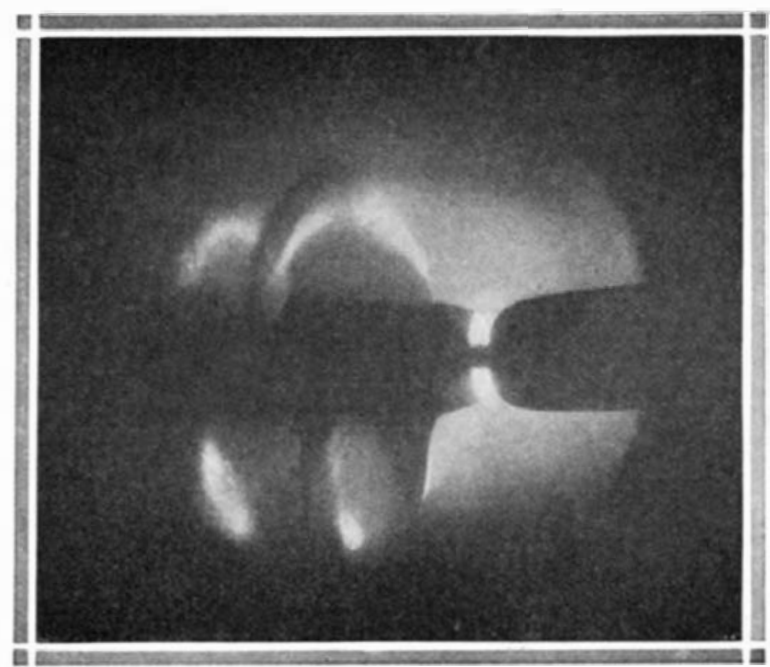

Photograph showing cavitation. The whitish arcs are the air spaces of cavitation, formed back of the propeller blades, which cause great loss of power moorings a message came from Prince Henry of Prussi: the Kaiser's brother, asking if I would repeat the rul as a personal favor to him. We had visitors, including ladies, on board at the time, and were not prepared for another cruise at such short notice, but there was no help for it and I gave the necessiry orders. In a fer minutes we were off again, racing merrily over the course at 34 knots. It seems that Prince Henry was much impressed, for he sent his engineer officers acros to inspect the 'Turbinia,' which they did with charac teristic German thoroughness."

After this dramatic display of what the new method of propulsion could do, the British Admiralty deemed it time to avail themselves of the inventor's genius. They therefore ordered a destroyer to be built and equipped with turbine engines, but placed the entire responsibility for the result on Mr. Parsons' shoulders. The "Viper," which was thus the first turbine-driven warship in the world, was 210 feet long by 21 feet beam and displaced 370 tons. The contract called for a guaranteed speed of 31 knots. The "Viper's" trials resulted in a complete triumph for the new motor. He fastest run was made at a speed of no less than 37.113 knots, the turbines developing 12,300 horsepower. The "Cobra," a similar but slightly larger destroyer, wa luilt at about the same time, and she, too, attained a very high speed. By a most unfortunate mischance, however, both vessels were lost soon after they hat been completed-the "Viper" in August, 1901, by running ashore during maneuvers, and the "Cobra" in the following month by foundering in a North Sea gale with reat loss of life. Although neither was due in any respect to the turbines, the effect of these two disaster was to damp the enthusiasm of the naval authorities, and several years passed before a new turbine-driven man-of-war was ordered. Merchant shipowners proved equally conservative. The inventor himself was confident that turbine machinery was particularly well suited for hich-speed mercantile ships, such as crossChannel boats and Atlantic liners. Its adoption would he predicted, effect a reduction in weight of machinery and an increased economy of fuel. Finally, as no shipping firm seemed disposed to take the first step, Mr. Parsons' own firm cooperated with Messrs. Denny, of Dumbarton, and several gentlemen interested in the system, in building a turbine steamer for passenge service on the Clyde Estuary. This vessel, the "K.ing Edward," was built in 1901. She soon asserted her superiority over the paddle steamers engaged on the same route, and her success at last induced the South Eastern Railway Company to order the first turbine steamer for the cross-Channel service between Dover and Calais. "The Queen," as this ship was named, more than realized expectations as to speed, economy, and general efficiency. The ice having thus been broken, orders for other turbine vessels, mainly cross- 
Channel boats and private yachts, began to flow in The first large ocean-going ship to be fitted with turbines was completed in 1904, and in the same year the Allan Line ordered two transatlantic liners, "Virginian" and "Victorian," to be engined on the same principle. Twelve months later Mr. Parsons had the gratification of learning that the Cunard Company had decided to install his system of propulsion in the twin ocean giants, "Mauretania" and "Lusitania."

Meanwhile, however, the turbine was making equally rapid progress in the naval sphere. When, in 1902, the Admiralty laid down four light cruisers of identical design, they ordered one ship, the "Amethyst," to be equipped with turbines, her three sisters .having reciprocating engines, When comparative trials were held, the superiority of the "Amethyst" was demonstrated so conclusivelyshe attained 23.63 knots, while the maximum speed of the other three was 22.34 knots-that the committee which had assembled to determine the characteristics of the Dreadnought recommended that turbine machinery be adopted for the world's first all-big-gun battleship. From that time onward the turbine became the standard motor of the British Navy, and other admira ties soon fell into line. In view of all that has been heard of German enterprise, it is interesting to recall that German marine engineers were bitterly opposed to the introduction of the turbine into their navy, and did not abate their hostility until repeated trials had left no doubt in reasonable minds as to the marked and all-round superiority of the new system for naval purposes. Of the subsequent history of the steam turbine it is unnecessary to speak here. Even before the war it had completely ousted the reciprocating engine in the navies of the world and was being almost universally adopted for the larger types of merchan vessels. Today its supremacy in the steam world is unchallenged, though there are indications that the internal-combustion engine will eventually become a serious rival.

The author of this outstanding achievement in the annals of engineering progress is a quiet and unassum ing gentleman, who shows signs of embarrassment when you speak of his work in glowing terms. In convers sity transitory-what is accomplished by one man being undone by another-the work of the scientific discoverer and in ventor is everlasting. However insigniticant this work may apparently be, provided it is new it adds something more to that great store of human knowledge and experience which is slowly accumulat ing and enables man more and more to triumph over nature."

\section{Iron and Steel in Brazil}

MPORTANT developments in the na1 tional iron and steel industry have taken place in Brazil during the past year. These developments represent phase of the Brazilian Government's policy to give the nation a greater degree of economic self-sufficiency by utilizing such resources as exist in the country. The object is to supply the home market for iron and steel and eventually to produce a surplus for export to other South American Republics.

Iron and steel manufactures are developing rapidly in Brazil, especially in Sao Paulo. The products of this industry include nails, screws and bolts, chains, woven fence wire, agricultural implements, enameled iron ware, rolling doors, the turbine craft (100 ft. long, 2000 horsepower) to demons British fleet at Spithead Review at 34 knots in 1897

tion with him one gets the impression that here is a great workman to whom work is not the means to an end, but an end in itself. Notwithstanding a life of study and untiring industry, he retains all the enthusiasm of youth, together with a simple kindliness of manner and an old-world courtesy that endears him to all with whom he comes into contact. To Sir Charle Parsons there are few higher vocations in life than those of the scientist and the improver of arts and manufactures. Here, in his own words, are his views on the subject. "Can it be questioned that the discoveries of Archimedes and his disciples have more effect today than the battles of Alexander or of Hannibal? of, if we turn to modern times, can it be gainsaid that Watt and Stephenson, Davy and Faraday, have done conditions of life than did Napoleon or Wellington, Walpole or Pitt? No less a statesman than the late Lord Salisbury once said, that while the work of the politician, the statesman, the soldier, or the leader of safes, stoves, and a great variety of general foundry work.

The basis of the Brazilian industry is the vast stores of high-grade hematite and magnetite ore existing in Minas Geraes and to a lesser degree in several other States, including Sao Paulo and Parana. It has been estimated by competent geologists that the total ore content of these fields is between $6,000,000,000$ and $12,000,000,000$ tons of hematite, a very large proportion of which runs over 60 per cent iron This is exclusive of the lesser volume of magnetite ores.

Both the present Federal Administration and the Governments of Minas and Sao Paulo have pursued a policy try. Liberal concessions have been granted to several companies, the principal favors consisting of exemption from import duties on equipment and from other taxes over a long period of years. Also, guaranties of substantial Government purchases have been given, and recently the policy has been adopted of making loans to metallurgical concerns. of encouraging the growth of an iron and steel indus-

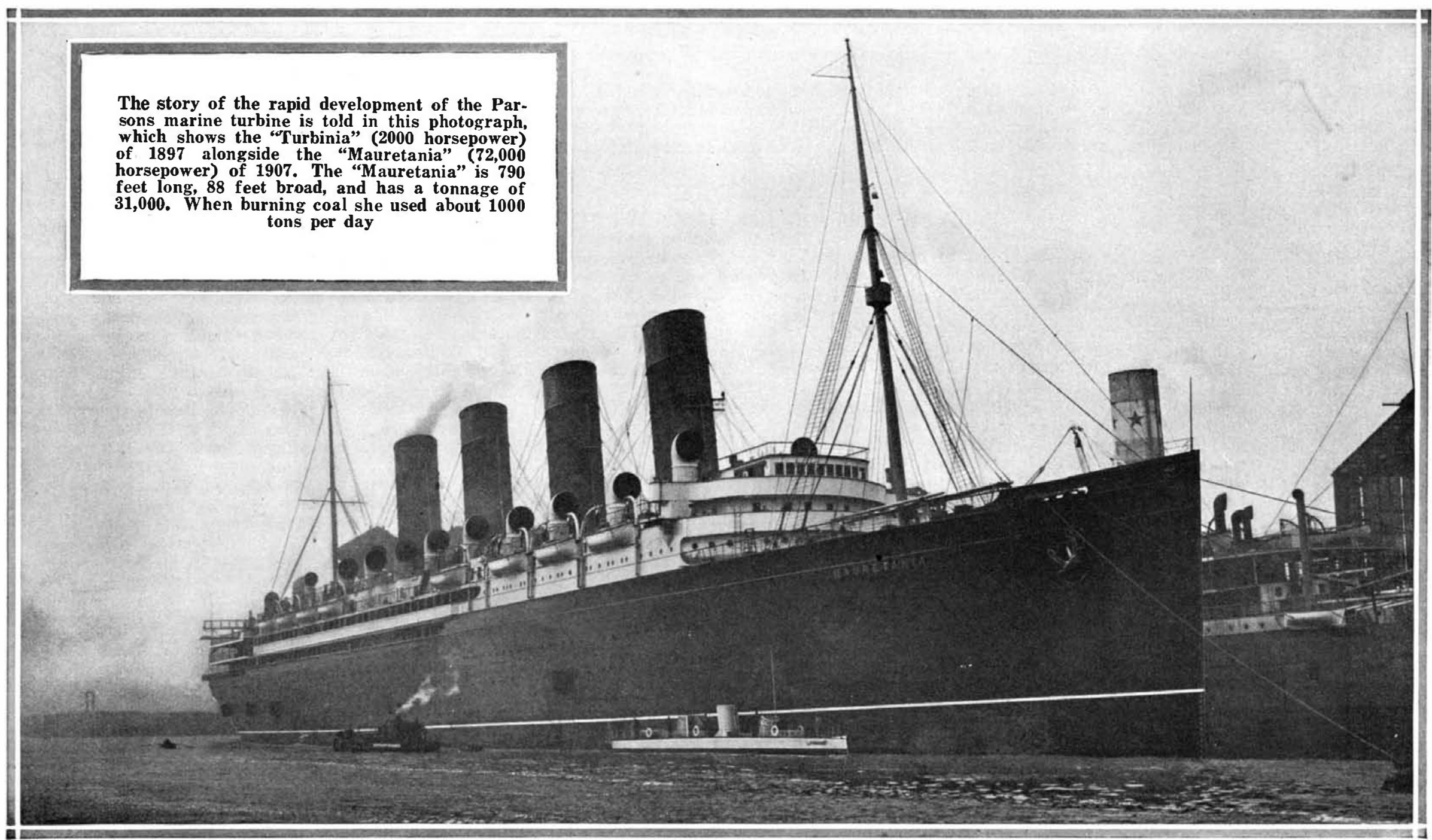

